\title{
Humanização na formação interprofissional: uma análise documental
}

\author{
Lucilene Martorelli Ortiz Medeiros, Sylvia Helena Souza da Silva Batista
}

\section{Resumo}

INTRODUÇÃO A análise desenvolvida aqui inscreve-se no marco do Sistema Único de Saúde (SUS), implementado pela Constituição de 1988 e instituído pela lei $\mathrm{n}^{\circ} .8 .080$, de 19 de setembro de 1990, a Lei Orgânica da Saúde (Brasil, 1990). Souza e Moreira (2008) considera o princípio da integralidade da atenção à saúde fundamental para se pensar a graduação em saúde e em mudanças que deveriam ser assumidas na interface entre educação e saúde, garantindo a humanização na formação em saúde centrada na interprofissionalidade e na interdisciplinaridade. Os conceitos de humanização e interdisciplinaridade deveriam ser princípios norteadores "das necessárias transformações nas graduações em saúde, orientando-as para as necessidades do SUS e da população" conforme propostos por Souza e Moreira (2008), o que contribuiria para direcionar os profissionais para o trabalho em equipes multiprofissionais e interdisciplinares. OBJETIVOS Analisar as concepções de humanização presentes nos Projetos Político-Pedagógicos do Campus Baixada Santista/Unifesp e dos Cursos Psicologia, Nutrição, Terapia Ocupacional, Fisioterapia, Educação Física e Serviço Social. Discutir as concepções de humanização presentes em artigos publicados na base de dados SciElo, no campo da formação em saúde no período de 2000 a 2012 MÉTODOS A metodologia de pesquisa abrangeu duas fases de análise documental: a primeira abrange os textos dos PPPs dos cursos da saúde do Campus Baixada Santista /Unifesp e a segunda refere-se à literatura. Na primeira análise documental foram privilegiados os seguintes documentos: PPP do Campus Baixada Santista da Unifesp e os PPCs dos cursos de Psicologia, Nutrição, Terapia Ocupacional, Fisioterapia, Educação Física e Serviço Social. As propostas contidas nos PPCs apresentam como princípio a Educação Interprofissional, onde são privilegiadas a "Integralidade" e a "Interdisciplinaridade" consonantes com o preconizado na Política Nacional de Humanização e nas Diretrizes Curriculares Nacionais dos cursos de Graduação em Saúde. Foi feito um protocolo de Análise Documental, para categorização dos dados obtidos. Na análise da literatura os descritores utilizados foram Humanização, Humanismo e Humanização na Formação. Selecionamos 23 artigos e a análise dos dados abrangeu caracterização das publicações e discussão das concepções de humanização presentes nos documentos analisados. Após a produção da análise documental, procederam-se a organização e análise dos dados. Optou-se por utilizar a análise temática, conforme descrito por Minayo (2004), buscando os núcleos de sentido presentes no material analisado. RESULTADOS I. AS VOZES DOS PPCs Procedeu-se à apreensão das concepções de humanização nos PPCs em duas etapas: a primeira, a partir das palavras Humanismo, Formação Humanística, Política Nacional de Humanização e Prática Humanizada/Humanística; a segunda, a partir das expressões: ética, cuidar/cuidado, integralidade, comunicação, relação com o paciente, relação pessoal/relacionamento interpessoal. Os conceitos de humanização mais presentes nos PPPs são os que se referem à Formação humanística citadas nos PPP do Campus Baixada Santista (2) e nos PPCs de Educação Física, Fisioterapia e Terapia Ocupacional, seguidas das expressões Humanismo e Prática Humanizada/Humanística nos PPCs de Serviço Social e Terapia Ocupacional, respectivamente. A expressão Política Nacional de Humanização não foi citada em nenhum dos PPPs. Na segunda análise, encontramos as expressões Ética, Cuidar/Cuidado, Comunicação, Integralidade referidas. Há um silêncio quanto às as expressões Relação com o Paciente e Relação Pessoal/ Relacionamento Interpessoal não foram localizadas. II. AS VOZES DA LITERATURA 2.1 CONCEPÇÕES DE HUMANIZAÇÃO As concepções de humanização abrangem múltiplas facetas: apontam para a ética nos relacionamentos, na garantia da comunicação com o outro, no 
ISSN 2179-6750

cuidar do outro, no bom convívio social; outros consideraram fundamental investir na reflexão do tema enquanto um conceito que orienta práticas, para que não se perdesse seu potencial transformador, acabando como mera repetição de uma palavra de ordem vazia e sem sentido. Por outro lado, encontramos considerações importantes sobre a não preocupação com definições sobre o tema, e, sim, o que a humanização produz. Com referência ao processo de formação, os sentidos da humanização apontam a importância da relação professor-aluno como relevantes para a formação em saúde. Pode-se apreender também, das pesquisas realizadas que a relação do profissional de saúde e os pacientes é imprescindível para que a humanização esteja presente nos atendimentos. As relações humanas são o princípio de toda prática humanizadora, na qual o conhecimento técnico deve estar aliado à sensibilidade, à afetividade e ao comportamento ético-profissional. CONCLUSÕES As concepções de humanização encontradas nos PPPs do Campus e seus cursos apresentam ênfases diferenciadas: Ética, Cuidar/Cuidado, Integralidade e Comunicação. Essas dimensões emergiram dos princípios e conduta ética, da integralidade do cuidado, do olhar de cuidado, da produção e modos de cuidar, da integralidade na atenção e do cuidado em saúde, da comunicação verbal e não verbal, enfim, da comunicação humana. Aprendeu-se que os significados encontrados na expressão Cuidar/Cuidado explicitam o compromisso com a Educação Interprofissional na Formação em Saúde e a competência para a integralidade do cuidado. A literatura investigada apresenta uma polissemia em relação à humanização: a ética nos relacionamentos, o cuidar/comunicar com o outro, pensar sobre o tema enquanto um conceito que orienta práticas, e o que considero muito importante, refletir sobre o que a humanização produz. $\mathrm{O}$ termo humanização nos remete, também, a Atitude, a um modo de Entender, de Fazer, de Ser e Conviver com as pessoas. É como o profissional se implica com as questões de saúde e as formas de resolubilidade das demandas. Com relação a formação se faz necessário a utilização de diferentes estratégias pedagógicas e diferentes cenários de aprendizagem significativa, superando a mera transmissão de conteúdo. No trabalho espera- se do profissional afetividade, sensibilidade, escuta qualificada para o acolhimento do usuário, pautando sua atuação em uma ética nas relações de trabalho. Entendo que assim como os significados encontrados na expressão Cuidar/Cuidado explicitam o compromisso com a educação interprofissional na formação em saúde com foco na integralidade no cuidado. É necessário investigar os "silêncios" encontrados buscando desvelar seus sentidos no campo da formação humanizada em um contexto de currículo interprofissional em saúde. A humanização revela-se como um processo complexo e amplo que envolve condições institucionais e pessoais, acolhimento, sensibilidade, valorização e interesse pela história do outro.

Descritores: Humanismo, Educação, Relações Interprofissionais 